BULLETIN Bulletin hispanique

HISPANIQUE Université Michel de Montaigne Bordeaux

121-1 | 2019

La épica en el mundo hispánico (Siglo de Oro)

\title{
Rafael Saravia, El abrazo contrario
}

Madrid: Bartleby Editores, 2017

Miguel Ángel Contreras

\section{(2) OpenEdition}

Journals

Edición electrónica

URL: https://journals.openedition.org/bulletinhispanique/8281

DOI: 10.4000/bulletinhispanique.8281

ISSN: 1775-3821

Editor

Presses universitaires de Bordeaux

Edición impresa

Fecha de publicación: 24 junio 2019

Paginación: 398-400

ISBN: 979-10-300-0363-5

ISSN: 0007-4640

Referencia electrónica

Miguel Ángel Contreras, «Rafael Saravia, El abrazo contrario», Bulletin hispanique [En línea], 121-1 | 2019,

Publicado el 24 junio 2019, consultado el 02 enero 2023. URL: http://journals.openedition.org/

bulletinhispanique/8281 ; DOI: https://doi.org/10.4000/bulletinhispanique.8281

Este documento fue generado automáticamente el 2 enero 2023.

All rights reserved 


\title{
Rafael Saravia, El abrazo contrario
}

\author{
Madrid: Bartleby Editores, 2017
}

Miguel Ángel Contreras

\section{REFERENCIA}

Rafael Saravia, El abrazo contrario. Madrid: Bartleby Editores, 2017. 75 p.

1 Los gestos y actitudes cotidianas percibidos desde perspectivas poco habituales y ofrecidos, a veces, en sus aspectos más contradictorios -cuando no directamente antagónicos- guardan algunas de las claves de los símbolos vertebradores de esa etapa de plenitud lírica en la que se encuentra, en sus últimas entregas, la poesía de Rafael Saravia (Málaga, 1978). Llorar lo alegre (Madrid, Bartleby Editores, 2011) será en ese sentido un punto de inflexión en la indagación que el poeta lleva a cabo por distintas estampas de su infancia, así como por territorios amatorios y sentimientos enfrentados que con sus incertidumbres emergerán al amparo de una nueva mirada, donde abrigar desengaños no implica una realidad dolorosa. Carta blanca (Madrid, Calambur, 2013) constituirá más adelante un insistir en la conciencia por itinerarios donde la mirada introspectiva del poeta se alternará con la búsqueda hacia fuera y la exploración de todo lo que exteriormente le rodea para construir un discurso lírico con el que nos sumergirá en los senderos de nuestra existencia por la vía de las pasiones, el amor o el compromiso ético.

2 En esta línea, el abrazo representa una de las expresiones que mejor nos caracteriza desde lo más humano: dos personas unidas por un mismo gesto que encierra y simboliza afectividad, generosidad y emoción en todas sus posibles variables. Pero en una época donde la perplejidad es -en tantas ocasiones- la pauta social dominante que sirve para aislar y alienar al individuo fomentando su egoísmo y estupidez y arrastrándolo a un antagonismo conceptual, donde todo aquello que nos es propio acaba invirtiendo el sentido que alguna vez tuvo, un tiempo así podría estar bien retratado por el título de la última entrega lírica de Rafael Saravia. El abrazo contrario es una obra de madurez y sosiego, fruto de las percepciones reposadas de un poeta que 
anhela actitudes diferentes ante el vértigo de tiempos que enmascaran al ser humano tanto en su ámbito público como en el íntimo y privado.

Vivencias, ensueños y fantasmas se plasman desde un tono sereno y reflexivo donde el "yo" lírico y el "sujeto poético" abren también una puerta a la voz como "sujeto social", una apuesta tan arriesgada como necesaria llevada a buen fin gracias a un discurso que se prolonga en su recepción con facilidad por la percepción de una realidad intimista, personal e intuitiva, todo ello tejido a partir de un lenguaje envolvente muy cuidado. $Y$ es que su "yo" lírico vive el desconcierto propio y ajeno de un mundo fragmentado, incoherente y cubierto por un extraño sentido de provisionalidad, un mundo carente de fraternidad entre sus individuos. Sujeto social, sujeto afectivo, El abrazo contrario viene precedido y abrigado por los versículos que forman el frontispicio y su nota de Antonio Gamoneda, un verdadero regalo para el lector y un preludio que nos invita a adentrarnos en un poemario sólido y valiente donde Rafael Saravia, en palabras del propio Gamoneda, «no se encogió ante la insurgencia de claves, de juicios -explícitos o implícitos- que sentenciaban la realidad "abrazada" (la diversa realidad existencial, social y política que a casi todos nos duele)» (p. 11).

4 El abrazo contrario nos ofrece un discurso articulado en torno a tres partes de una singular geometría: "Barrios de sal”, "Tejer fronteras" y "Derramas de luz", cada una compuesta por poemas titulados con numeración romana correlativa entre sí que se alternan con otros de títulos más habituales formando en su combinación aleatoria una particular asimetría de quince, doce y catorce poemas, respectivamente. Todas esas partes están precedidas por citas de Pier Paolo Pasolini, Antoine de Saint-Exupéry y William Blake que marcarán de manera vertebradora la temperatura dominante del conjunto.

De este modo, en "Barrios de sal" sentimos la voz poética escrutar desde su conciencia en la aparente libertad del individuo en sus distintos ámbitos, así como en sus deseos, luchas y desencuentros como fruto especulativo de «la mordedura de lobo / que se aferra a los tobillos del desconcierto» (p. 17). Tiempos de transición y de cambio de todo aquello que alguna vez fue, donde «la memoria se contagia de espacio sin finalidad / y la anarquía cobra sentido» (p. 25). Una voz conocedora por sus heridas de la facilidad con la que «el dolor se acomoda en la inmovilidad» (p. 28) para sumergirnos y arrastrarnos en la confusión. Será su capacidad de reconocerse en la complejidad de las realidades sociales y afectivas la que subraye para su autoafirmación esa fuente vital que representa el «lugar donde el ego repone energía, / las tremendas necesidades del sexo y sus tambores...» (p. 30).

6 “Tejer fronteras" nos dirige por otros contornos más íntimos en los que el "yo" lírico se encuentra marcado por sus pasiones, ausencias y soledad, intentando «inclinar lo solvente hasta aguantar el tiempo y su imparcialidad» (p. 41). Son enclaves de una búsqueda constante que pretende indagar en la cartografía de los afectos para «conocer, / a través de lo transparente, / la amalgama que contagia mi buen sabor por ti» (p. 50), aún a riesgo de que sea el amor a veces el causante de «un dolor apuntalado en su angustia y su frío sano» (p.51). Será el deambular por los laberintos de la distancia en historias que se bifurcan y la disyuntiva que provoca el despertar de otras lo que le llevará «a tomar el tiempo y su necesidad de no acomodo» (p. 53).

Cierra el libro con determinación "Derramas de luz", donde los diferentes territorios físicos y emotivos se superponen en un mismo plano -«las piedras próximas amamantaban líquenes y vejez dominical» (p.59)- con el único afán de defender 
espacios más habitables. Encontraremos en esta última parte las claves que dan sentido al título del poemario cuando «se descuelga el necesario alimento de la necesidad misma. / Lo correcto y su dolor permanente» (p. 60). La prolongación de esa memoria atemporal para «fracturar el tiempo incómodo y poder mirar, / sin más, / el calor azul de lo importante» (p.60) es lo que le permitirá al poeta la construcción reflexiva de un universo en el que los afectos, el paisaje compartido y el compromiso social se vertebren en un discurso lúcido y arriesgado, aunque este pueda culminar con algún «presagio que nos haga llorar / antes de cada abrazo contrario» (p. 74).

Obra luminosa y atrevida que debemos agradecerle a Rafael Saravia por la determinación y el arrojo en afrontar el caos de esta realidad líquida en la que a menudo nos ahogamos. El amor, el sexo, la incomunicación, el desarraigo afectivo, la especulación o el deterioro medioambiental son en definitiva la materia de la que se nutre ese abrazo circundante e inverso que nos descubre. Un buen asidero para sobrellevar el derrumbe colectivo producido por el hallazgo diario de que nada es lo que alguna vez pudimos apreciar en verdad.

\section{AUTORES}

\section{MIGUEL ÁNGEL CONTRERAS}

Granada - España 